\title{
Impact of Amino Acids and Humic Substances Application on Some Soil Chemical Properties Along with Nutritional Status and Productivity of Wheat Grown under Saline Conditions Mona H. M. Kenawy Soil, Water and Environ. Res. Inst., Agric. Res. Center, Giza, Egypt
}

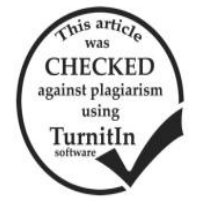

\section{ABSTRACT}

A field experiment was carried out on saline sandy clay loam soil at Gelbana Village District Sahl-el Tina, North Sinai Governorate, Egypt during two successive winter seasons (2013/2014 and 2014/2015) to study the effect of amino acids (A), humic substances $(\mathrm{H})$ and amino humate $(\mathrm{AH})$ on soil chemical properties along with nutritional status and productivity of wheat grown under salinity stress condition, using a complete randomized block design with three replicates. The soil was irrigated from El-Salam Canal (a mixture of Nile and agricultural drainage water) .Two rates of amino acids (5Lfed $\left.{ }^{-1}\right)$ and $\left(10 \mathrm{Lfed}^{-1}\right)$ along with two rates of humic substances $\left(5 \mathrm{Lfed}^{-1}\right)$ and $\left(10 \mathrm{Lfed}^{-1}\right)$ as well as two rates of amino humate $\left(5 \mathrm{Lfed}^{-1}\right)$ and $\left(10 \mathrm{Lfed}^{-1}\right)$ were applied. Results indicated that $\mathrm{pH}$ values of the soil after harvesting were slightly decreased as affected by all studied treatments for both tested seasons. Values of EC and ESP were, however, positively affected being with lowest EC values recorded in presence of humic substances (H2) treatment at both tested seasons. Positive response was detected for each of CEC, O.M, nutrient availability in soil after harvesting as well as content of (N,P and K) for straw and grains, the second rate of amino acid (A2) giving the highest values of available $\mathrm{N}$ followed by the second rate of amino humate (AH2); as well as the high rate of humic substances (H2) was more responded for increasing $\mathrm{P}, \mathrm{K}$ availability followed by the second rate of amino humate (AH2). Generally, applied treatments increased significantly soil micronutrients ( $\mathrm{Fe}, \mathrm{Mn}, \mathrm{Zn}$ and $\mathrm{Cu})$ availability as compared to control treatment at both studied seasons; increasing the rate of applied amino acids and humic substances caused a significant gradual increase for both studied seasons under investigation. Amino humate (AH2) treatment gave the highest values of $(\mathrm{N}, \mathrm{P}$ and $\mathrm{K})$ content of grains and straw for wheat at both studied seasons as compared to (AH1) treatment. $\mathrm{K} / \mathrm{Na}$ ratio increased gradually by increasing the rate of applied treatments; such positive effect of both tested seasons may be arranged in descending order : amino-humate $2>$ amino acid $2>$ humic sub. $2>$ amino-humate $1>$ amino acid $1>$ humic sub 1 as compared to control. Increasing the rate each of amino acids and humic substances caused a significant gradual increase in straw and grains of wheat for both studied seasons ; humic sub.( H2 ) was superior as compared with amino acid (A1) which was the inferior. The application of humic sub.(H2) recorded a relatively superior in yield percentage components of wheat crop as compared to control. Amino humate 2 was effective on both yield components of straw and grains as compared to ( amino humate1) for both studied season. Protein and proline content s increased significantly in presence of both amino acids and humic substances along with their combination (amino humate ) as compared to control, the high rate of amino acids (A2) being more effective. Leaf total chlorophyll content (A, B and A+B) increased gradually by increasing the rate of applied treatments, high rate of amino acids (A2) being superior as compared to control and other treatments.

Keywords: Amino acid-humic substance-amino humate- soil chemical properties-nutritional status-saline condition-wheat yield.

\section{INTRODUCTION}

Wheat (Triticum aestivum L.) is cultivated primarily as a food strategic commodity. Wheat is the leading source of vegetable protein in human food, (FAO 2004).

Salinity of soil is one of the most important problems in arid and semi-arid regions of the world reducing the yield crops. The salinization and alkalinisation induce certain physical and chemical soil characters, which should have a profound effect on the agro-ecosystem. The excess exchangeable sodium $(\mathrm{Na})$ and the high soil $\mathrm{pH}$, cause deformation of soil structure and decrease in hydraulic conductivity of soils (Lauchli and Epstein, 1990). These processes, which affect plant growth, are related to increasing in the concentration of salt in the root zone, as water is removed from the soil profile due evapotranspiration. The accumulation of $\mathrm{Na}+$ causes the antiparticle distance to continuously increase and the individual clay particles to disperse elongation. The mechanisms of growth inhibition include disturbance of plant water retention, because of the high osmotic potential of the external medium as well as adverse effects on photosynthesis and protein synthesis (Romero-Aranda et al., 2001).

The reclamation of salt affected soil requires an improvement of physical, chemical and biological properties. Recently, humic acid-rich materials are widely used as soil conditioners and growth regulators. Moreover, several studies have demonstrated that the application of humic acid has many benefits for salt-affected soils. Kulikova et al. (2005) mentioned that, humic substances possibly counteract the negative effects of salinity conditions by reducing the uptake of some toxic elements. Brady and Weil (2008) reported that humic substances, increase soil water retention, infiltration rate, water-holding capacity as as well the cation exchange capacity. Aydin et al. (2012) found that, addition of humic acids to saline soils were reduced the soil electrical conductivity. Khattak et al. (2013) found that, cation exchange capacity (CEC) was improved with additions of HA to saline-sodic soil. Jiangkuan et al. (2015) added that, presence of humic acid increased the replace of exchangeable $\mathrm{Na}^{+}$from the soil surface .

Canellas et al.(2002) suggested that, humic substances (HS) have a plant growth promoter by changes on root elongation and growth dynamics, which increased root size as well as density of root hair. Tahir et al. (2012) found that, wheat growth enhanced by humic acid treatments through chelating unavailable nutrients as well as buffering soil $\mathrm{pH}$ and increasing macronutrient uptake.

Amino acids act as precursors of other nitrogen containing compounds. Plants subjected to stress show accumulation of proline and other amino acids which varies from acting as osmolyte and modulating stomatal opening. Amino acids also affect synthesis of some enzymes (Rai, 2002). Wendell (2002) summarized the benefits of using amino acids in the fertility program to the fact that amino acids is zwitter ions in soil solution and 
thus can attach to the clay colloids in soil to be not lost to the surrounding environment. Also, Sekhon (2003) reported that, natural amino acids have the ability to chelate the micro-nutrients in soil solution and hence their rapidly absorbed, translocate and metabolized by plants; such amino acids have traditionally been considered as precursors of proteins.

Abd El-Samad et al. (2010) found that, treated soil with amino acids possibly counteract the negative effects of salinity and promote the plant growth . Gioseffi et al (2012) mentioned that, amino acids contain a significant amount of nitrogen source for wheat plants. Calvo et al.(2014), showed that protein hydrolysates and specific amino acids can induce plant defense responses through increase plant tolerance to a variety of abiotic stresses, including salinity.

Ertani et al. (2009) observed that application of plant-derived protein (amino acid) on plants increased nutrient uptake, especially nitrogen and iron, as a result of increased nitrate reductase and glutamine synthetase activities and $\mathrm{Fe}(\mathrm{III})$ chelate reductase activity, respectively. Protein (amino acid) can improve crop tolerance to abiotic stresses as reported by Ertani et al. (2013) who observed that root applications of the amino acids( derived-protein hydrolysate) improved salinity tolerance of corn due to a better nitrogen metabolism, and a higher $\mathrm{K} / \mathrm{Na}$ ratio with proline accumulation in leaves. Colla et al.(2014) reported that, application of protein containing amino acids enhanced nitrogen uptake and crop performances.

Finally, the main target of the present study was to investigate the mitigation effect of amino acids, humic substances and their combination on soil chemical properties, nutritional status and wheat yield productivity under salinity stress condition.

\section{MATERIALS AND METHODS}

A field experiment was carried out on a saline sandy clay loam soil at Gelbana Village District, Sahl-el Tina, North Sinai Governorate, Egypt during two successive winter seasons (2013/2014 and 2014/2015) using a randomized complete block design with three replicates, The plot area being $24 \mathrm{~m}^{2}$ ( $3 \mathrm{~m}$ width and $8 \mathrm{~m}$ length). The soil was irrigated from El-Salam Canal (a mixture of Nile water and agricultural drainage water) . wheat was the used crop.

The soil under study was analyzed according to Cottenie et al. (1982) and described in (Table 1).

Table 1. Some physical and chemical properties of the experimental soil.

\begin{tabular}{|c|c|c|c|c|c|c|c|c|c|c|}
\hline Course sand(\%) & \multicolumn{3}{|c|}{ Fine sand (\%) } & Silt (\%) & Clay (\%) & \multicolumn{2}{|c|}{ Texture } & \multicolumn{2}{|c|}{ O.M $\left(\mathrm{g} \mathrm{kg}^{-1}\right)$} & $\mathrm{CaCO}_{3}\left(\mathrm{~g} \mathrm{~kg}^{-1}\right)$ \\
\hline 6.83 & \multicolumn{3}{|c|}{56.73} & 16.22 & 20.12 & Sandy & ay loam & 6. & & 5.69 \\
\hline \multirow{2}{*}{$\begin{array}{l}\text { pH (1:2.5) (Soil: } \\
\text { water suspension) }\end{array}$} & EC & SAR & ESP & \multicolumn{4}{|c|}{ Soluble Cations (mmolc $\left.\mathbf{L}^{-1}\right)$} & \multicolumn{3}{|c|}{ Soluble Anions (mmolc $\left.\mathrm{L}^{-1}\right)$} \\
\hline & $\left(\mathrm{dSm}^{-1}\right)$ & $\%$ & $\%$ & $\mathrm{Ca}^{++}$ & $\mathbf{M g}^{++}$ & $\mathrm{Na}^{+}$ & $\mathbf{K}^{+}$ & $\mathrm{HCO}_{3}^{-}$ & $\mathrm{Cl}^{-}$ & $\mathrm{SO}_{4}^{-}$ \\
\hline 8.1 & 8.57 & 12.12 & 14.15 & 14.66 & 19.81 & 50.31 & 0.92 & 7.36 & 49.98 & 26.52 \\
\hline \multicolumn{5}{|c|}{ Available macronutrients (mg kg $\left.{ }^{-1}\right)$} & \multicolumn{6}{|c|}{ Available micronutrients $\left(\mathrm{mg} \mathrm{kg}^{-1}\right)$} \\
\hline $\mathbf{N}$ & & $\mathbf{P}$ & & $\mathbf{K}$ & $\mathbf{F e}$ & & & $\mathbf{M}$ & & $\mathrm{Cu}$ \\
\hline 79.2 & & 5.77 & & 189 & 4.13 & & & 3.2 & & 0.64 \\
\hline
\end{tabular}

\section{Soil tillage:}

Soil surface was leveled using laser technique. Deep sub-soiling plough, and establishment of field drains were performed at a distance of $10 \mathrm{~m}$ between each of two drains at a depth of $90 \mathrm{~cm}$ at the drain beginning, establishment of an irrigation canal in the middle part of the experimental plot unit were carried out. The plot units were subjected to continuous and alternative leaching processes before wheat planting.

The experiment treatments :

1- Control treatment (con)

2- Amino acids at rate $5 \mathrm{~L} \mathrm{fed}^{-1}(\mathrm{~A} 1)$

3- Amino acids at rate $10 \mathrm{~L} \mathrm{fed}^{-1}(\mathrm{~A} 2)$

4- Humic acids at rate $5 \mathrm{~L} \mathrm{fed}^{-1}(\mathrm{H} 1)$

5 -Humic acids at rate $10 \mathrm{~L} \mathrm{fed}^{-1}(\mathrm{H} 2)$

6-Amino humat at rate $5 \mathrm{~L} \mathrm{fed}^{-1}(\mathrm{AH} 1)$

7-Amino humat at rate $10 \mathrm{~L} \mathrm{fed}^{-1}(\mathrm{AH} 2)$
All treatments received mineral fertilizers at the recommended doses for wheat crop. Superphosphate (15.5 $\% \mathrm{P}_{2} \mathrm{O}_{5}$ ) at a rate of $200 \mathrm{Kg}$ fed- 1 was added basically before sowing during soil preparation. Nitrogen was added at a rate of $340 \mathrm{Kg} \mathrm{fed}{ }^{-1}$, ammonium nitrate $(33.5 \% \mathrm{~N})$ applied in three split equal doses after 30 and 60 days from sowing. Finally, potassium was added as potassium sulfate $\left(48 \% \mathrm{~K}_{2} \mathrm{O}\right)$ at a rate of $50 \mathrm{Kg} \mathrm{fed}^{-1}$ in two equal doses at sowing and 30 days from sowing. Amino acids (A), humic substances $(\mathrm{H})$ and amino humate $(\mathrm{AH})$ treatments were sprayed on soil surface three times along the growth period (4,6 and 8 weeks) from planting.

Preparation of Amino acids (A) .

Amino acids (A) was prepared by acidic hydrolysis of dry yeast protein and adjusted to $\mathrm{pH} 6$ with alkaline hydrolysis of dry yeast protein ; included amino acids are shown in table (2) . Amino acids composition was determined by Amino acid analyzer apparatus.

Table 2. Amino acids composition $\%$ ( g/100ml)

\begin{tabular}{|c|c|c|c|c|c|c|c|c|}
\hline \multicolumn{9}{|c|}{ Amino acids composition $\%(g / 100 m l)$} \\
\hline Aspartic & Threonine & Serine & Glutamic & Proline & Glycine & lanine & Valine & Isoleucine \\
\hline 77 & & 1.51 & & 27 & & & 11 & \\
\hline & & ( & & & & & \multicolumn{2}{|c|}{ Methionine } \\
\hline 2.35 & & 1.18 & & & & & \multicolumn{2}{|c|}{0.70} \\
\hline \multicolumn{9}{|c|}{ 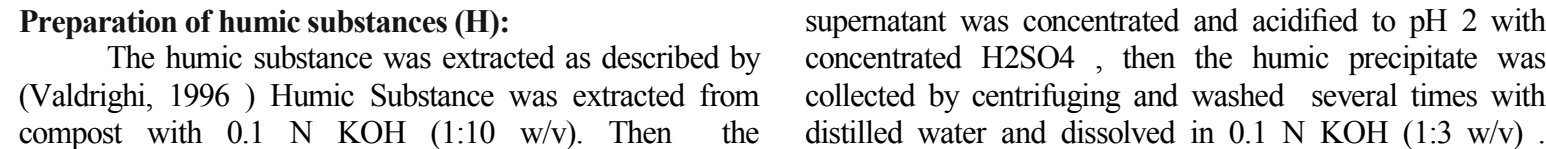 } \\
\hline
\end{tabular}


Adjustment to $\mathrm{pH}$ 6, by using citric acid, was thought to be useful in obtaining required effect on soil.

Preparation of amino humate (AH).

Amino humate $(\mathrm{AH})$ was prepared by mixing $\mathrm{A}$ and $\mathrm{H}(1: 1)$; Some characteristics of amino acids and humic substances a are presented in Table (3)

Table 3. Some characteristics of amino acids (A) and humic substances $(\mathrm{H})$.

\begin{tabular}{lcc}
\hline Characteristics & $\begin{array}{c}\text { Amino acids } \\
(\mathbf{A})\end{array}$ & $\begin{array}{c}\text { Humic } \\
\text { substances(H) }\end{array}$ \\
\hline $\mathrm{pH}$ & 6.00 & 6.00 \\
$\mathrm{EC}$ & 15.1 & 19.5 \\
Free amino acids\% $(\mathrm{g} / 100 \mathrm{ml})$ & 26.8 & Not detected \\
Humic acid\%(g/100ml) & Not detected & 25.0 \\
\hline Total nutrients) & & \\
$\mathrm{N}(\mathrm{g} / 100 \mathrm{ml})$ & 5.33 & 1.70 \\
$\mathrm{P}(\mathrm{g} / 100 \mathrm{ml})$ & 0.64 & 1.40 \\
$\mathrm{~K}(\mathrm{~g} / 100 \mathrm{ml})$ & 1.80 & 2.20 \\
$\mathrm{Fe}\left(\mathrm{mg} \mathrm{l}^{-1}\right)$ & 21.7 & 14.0 \\
$\mathrm{Mn}\left(\mathrm{mg} \mathrm{l}^{-1}\right)$ & 3.10 & 10.7 \\
$\mathrm{Zn}\left(\mathrm{mg} \mathrm{l}^{-1}\right)$ & 7.94 & 11.5 \\
$\mathrm{Cu}\left(\mathrm{mg} \mathrm{l}^{-1}\right)$ & 0.08 & 4.50 \\
\hline
\end{tabular}

\section{Soil analysis:}

Surface soil samples $(0-30 \mathrm{~cm})$ were taken at harvest stage and subjected to analysis of some soil chemical properties. Such surface soil samples were collected, air- dried, sieved to pass through a $2 \mathrm{~mm}$ sieve and mixed thoroughly. The soil reaction $(\mathrm{pH})$ was determined using a $\mathrm{pH}$ meter in soil suspension (1: 2.5) ; calcium carbonate, along with total soluble ions and electrical conductivity (EC) were evaluated in the saturated soil paste extracts, as well as sodium adsorption ratio (SAR) was calculated using the concentration of $\mathrm{Na}$ and $\mathrm{Ca}+\mathrm{Mg}\left(\mathrm{mmol} \mathrm{L}^{-1}\right)$ in soil extracts using the formula

Exchangeable sodium percentage (ESP) was estimated using the following equation

$\mathrm{ESP}=\mathrm{Na} \mathrm{exch}^{+} /\left[\mathrm{Caexch}^{2+}+\mathrm{Mgexch}^{2+}+\mathrm{Kexch}^{+}+\mathrm{Naexch}^{+}\right] \times 100$

All parameters were evaluated as described by Cottenie et al. (1982). Cations exchange capacity (c molc kg-1 soil) and organic matter (O.M) was determined according to Jackson (1967).

Available N,P,K and micronutrients were determined according to the method described by Jackson (1967) as follows:

Available nitrogen was measured according to the modified Kjeldahl method. Available phosphorus was extracted using $0.5 \mathrm{~N} \mathrm{Na} \mathrm{HCO}_{3}{ }^{-} \mathrm{HCO}_{3}{ }^{-}$solution at $\mathrm{pH} 8.5$ and determined calorimetrically. Available potassium was extracted using $1 \mathrm{~N}$ ammonium acetate at $\mathrm{pH} 7.0$ and determined calorimetrically . Available micronutrients ( $\mathrm{Fe}, \mathrm{Mn}, \mathrm{Zn}$, and $\mathrm{Cu}$ ) were extracted, using DTPA and determined using Atomic absorption Spectrometry apparatus.

\section{Plant analysis :}

Straw and grains of wheat crop, were collected from each plot, oven dried at $70^{\circ} \mathrm{C}$, and then weighed up to a constant dry weight, ground and prepared for digestion. The digests were then exposed to the estimation of N, P, K , Na and micronutrients according to Cottenie et al. (1982).

Grain protein content was calculated by multiplying grain $\mathrm{N}$ content by 5.75 according to Baker (1979).
Finally, Proline content was determined by the ninhydrin method as cited by Bates et al., (1973);chlorophylls A and B being measured after Lichtenthaler and Wellburn (1983) at pre flowering stage.

Obtained results were subjected to statistical analysis, according to Snedecor and Cochran (1980) and the treatments were compared using the least significant difference (L.S.D. at 0.05 level of probability).

\section{RESULTS AND DISCUSSION}

Presentation for the section of results and discussion was thought to include the effects of amino acids(A) , humic substance $(\mathrm{H})$ and amino humate $(\mathrm{AH})$ on each of chemical properties of soil ,nutrient availability, element status in grown plants, organic components and chlorophyll content of the concerned plants, along with crop yield .

\section{Chemical properties of soil:}

Data illustrated in Table (4) show the changes of some soil chemical properties as affected by the studied treatments of amino acids and Humic substance along with their combination, after wheat harvesting, under salinity conditions.

Soil (pH) :

Results revealed that, $\mathrm{pH}$ values of soil after plant harvesting, in general were slightly affected by the studied treatments; The values of $\mathrm{pH}$ were slightly decreased for both tested seasons .The second rate of amino acids (A2) was, however, the superior possibly due to carboxyl group $(-\mathrm{COOH})$ which can release $\mathrm{H}^{+}$to directly neutralize soil alkalinity. Such response may be also attributed to the suggestion of Jones et al (2013) who reported that, amino acids can be cleaved by extracellular enzymes or microorganisms releasing keto acids, $\mathrm{HCO}_{3}{ }^{-}$and $\mathrm{NH}_{4}{ }^{+}$.

The effect of humic substance on decreasing the soil $\mathrm{pH}$, on the other hand, could be explained by the effect of protons $\left(\mathrm{H}^{+}\right)$release from carboxyl $(-\mathrm{COOH})$ and phenolic hydroxyl $(-\mathrm{OH})$ groups to directly neutralize soil alkalinity, humic substance added to the soil could improve biological activity (Khattak et al. 2013) and thus promote the decomposition of soil organic matter. The decaying of organic matter present in humic substance increases the $\mathrm{CO}_{2}$ concentrations in the soil and releases $\mathrm{H}^{+}$ions which reduce the $\mathrm{pH}$ values (Wong et al. 2009).

\section{Electric conductivity (EC) and ESP:}

Data presented in Table (4) indicate that, values of EC and ESP were positively affected by amino acids application as compared to control treatment. This may be attributed to the amino acids ability to chelate ions so convert it to easily leaching. The lowest EC values were recorded with the Humic substance $(\mathrm{H} 2)$ treatment at both tested seasons, followed by the amino humate (AH2).These results are in agreement with those obtained by Aydin et al. (2012) who reported that, humic acid added to saline soil significantly reduced soil electric conductivity and attributed this effect due to the fact that HA absorbed many times their weight of water, which diluted the salt effect and store it for relatively long time ;such conditions facilitated leaching of soluble salts and decreased soil salinity. 


\section{Mona H. M. Kenawy}

With respect to the effect of humic substance and amino humate treatments on soil ESP, data pointed out that values were reduced significantly by increasing their rates compared to control. These results agree with those of Jiangkuan et al. (2015) who reported that, more exchangeable $\mathrm{Na}^{+}$was replaced from the soil colloid receiving humic acid. Moreover, Lakhdar et al., (2009) pointed that organic matter presence in HS decreased soil $\mathrm{Na}, \mathrm{EC}$ and $\mathrm{pH}$ values due to high supplies of $\mathrm{Ca}, \mathrm{Mg}$ and
$\mathrm{K}$; these mineral elements kept the cation-exchange sites on the soil particles to minimize adsorption of $\mathrm{Na}$, so enhancing $\mathrm{Na}$ leaching. Moreover, Ouni et al. (2014) added that, reduction of salinity means reduction for the monovalent $\mathrm{Na}^{+}$which thus is particularly evident when replaced by the monovalent $\mathrm{K}^{+}$of the humate. Thus, by electrostatic repulsion of the high concentration of $\mathrm{K}^{+}$ present in humic complex $\mathrm{Na}^{+}$of the adsorption colloid decreased which finally reduces the soil salinity.

Table 4. Effect of amino acids, humic substance and their combination, on some soil chemical properties of studied soil for both studied seasons.

\begin{tabular}{|c|c|c|c|c|c|c|c|c|c|c|}
\hline \multirow[b]{2}{*}{ Treatments } & \multicolumn{5}{|c|}{ First season } & \multicolumn{5}{|c|}{ Second season } \\
\hline & pH & $\begin{array}{c}\mathrm{EC} \\
\mathrm{dSm}^{1}{ }^{1}\end{array}$ & $\begin{array}{c}\text { ESP } \\
\%\end{array}$ & $\begin{array}{c}\text { CEC c molc } \\
\mathrm{kg}^{-1} \mathrm{l}\end{array}$ & $\underset{\text { g kg- }}{\mathrm{OM}}$ & pH & $\begin{array}{c}\text { EC } \\
\text { dSm- }^{1}\end{array}$ & $\begin{array}{c}\text { ESP } \\
\%\end{array}$ & $\begin{array}{c}\text { CEC } \\
\text { c molc kg-l }\end{array}$ & $\underset{\text { g kg- }^{1}}{\text { OM }}$ \\
\hline Control & 8.05 & 6.43 & 12.9 & 24.4 & 0.81 & 7.91 & 7.28 & 13.2 & 23.7 & 0.61 \\
\hline Amino Acids 1 & 7.82 & 6.12 & 12.50 & 27.4 & 0.98 & 7.77 & 7.15 & 12.8 & 26.6 & 0.68 \\
\hline Amino Acids 2 & 7.67 & 5.98 & 11.6 & 27.9 & 1.12 & 7.72 & 6.75 & 12.6 & 27.5 & 0.75 \\
\hline Humic substance 1 & 7.92 & 5.37 & 9.36 & 28.7 & 1.11 & 7.88 & 6.19 & 11.7 & 28.6 & 0.85 \\
\hline Humic substance 2 & 7.84 & 4.29 & 8.71 & 29.0 & 1.15 & 7.83 & 5.54 & 11.5 & 29.5 & 0.88 \\
\hline Amino humate $(\mathrm{AH}) 1$ & 7.89 & 5.53 & 9.96 & 28.6 & 1.07 & 7.88 & 6.66 & 11.90 & 28.36 & 0.76 \\
\hline Amino humate(AH) 2 & 7.88 & 4.96 & 8.83 & 28.9 & 1.08 & 7.83 & 5.93 & 11.70 & 28.73 & 0.81 \\
\hline LSD 0.05 & 0.181 & 0.49 & 0.541 & 0.146 & 0.115 & 0.116 & 0.549 & 0.789 & 0.172 & 0.07 \\
\hline
\end{tabular}

\section{Soil Cation Exchange Capacity (CEC):}

With respect to CEC values, data presented in Table (4) show positive response due to applied different treatments, during both tested seasons, as compared to control. Such values were increased by increasing the rate of either amino acids or humic substances and their combination (amino humate), possibly due to the fact that, amino acids can be attached to the clay colloids in soil through $\mathrm{NH}_{3}{ }^{+}$group , negative charge of(COO-) and other function groups in their side chain $(\mathrm{OH}-, \mathrm{SH}-)$.

These results are in agreement with those of Wendell (2002) who suggested the benefits of using amino acids in the fertility program; their zwitter ions in soil solution can attach to the clay colloids.

Humic substance 2 treatment was the superior for increasing the CEC value as compared to control and other treatments due to its high CEC (Bohn et al., 2001) .Also, Verlinden et al.(2009) pointed out that, humic substances behave like weak acid polyelectrolytes; the occurrence of anionic charged sites accounts for the ability to retain cations. Obtained results agree with those of Khattak et al.(2013) who found that, addition of 1.5 and $3.0 \mathrm{mg} \mathrm{kg}^{-}$ ${ }^{1} \mathrm{HA}$ to saline soil, increased CEC by 12.28 and $20.7 \%$ respectively over control . Of course, HA, as contributing to the CEC of the soil, can promote cation retention capacity thus regulate nutrient supply to plants.

\section{Soil organic matter (O.M):}

Data presented in Table (4), indicated that either amino acids, humic substance or their combinations significantly increased soil organic matter (O.M); the treatments followed the descending order of $\mathrm{H} 2>\mathrm{H} 1>$ $\mathrm{AH} 2>\mathrm{AH} 1>\mathrm{A} 2>\mathrm{A} 1>$ control for both tested seasons. These results may be probably due to the organic matter content $(65-70 \%)$ of humic substances. In fact, humic substances (humic and fulvic acids) are a vital constituent and an intimate part of soil organic Ouni et al. (2014).

Nutrient availability of studied soil at harvesting stage:

- Macronutrients (N, P and K)

Data presented in Table (5), show the availability of $\mathrm{N}, \mathrm{P}$ and $\mathrm{K}$ in the studied soil affected by the applied treatments. Data revealed that the values of available nutrients significantly increased by each of amino acids or humic substances either as individual or in combinations as compared to control.

Increasing the rate of applied amino acids from A 1 to A2 caused a significant increase in nitrogen availability for both studied seasons under investigation; the second rate of amino acid (A2) gave the highest values of available $\mathrm{N}$ as compared to control and other treatments. The same obtained results were recorded by Wendell (2002) who found that, the positive effect of amino acids was possibly due to their nature as organic $\mathrm{N}$ - source; moreover the benefits of using amino acids in the fertility program may be again, due to the zwitter ions in soil solution which can attach to the clay colloids in soil and thus will not be lost to the surrounding environment.

Regarding the humic substances, increasing the rate from $\mathrm{H} 1$ to $\mathrm{H} 2$ caused a significant increase in the studied nitrogen availability for both studied seasons under investigation as compared to control treatment through its prevention from leaching (Clapp, 2001)

The high rate of humic substances (H2) was also more effective for increasing $\mathrm{P}$ and $\mathrm{K}$ availability, possibly due to the effect of humic substances for increasing phosphorus recovery from calcium phosphate precipitates (Verlinden et al.,2009). Moreover, humic substances, as a result of their microorganisms activities, decrease soil $\mathrm{pH}$ and thus release fixed potassium and produce more chelating ions, leading to an increase in nutrient available forms of elements in the rhizosphere Zone ; these results are agree with those of Khaled and Fawy (2011).

\section{- Micronutrients :}

With respect to soil micronutrients availability ( $\mathrm{Fe}, \mathrm{Mn}, \mathrm{Zn}$ and $\mathrm{Cu}$ ), data presented in Table (5) revealed that all applied treatments increased significantly values of soil micronutrient available as compared to control treatment at both studied seasons, A2 being more effective than $\mathrm{A} 1$ and $\mathrm{H} 2$ being superior to H1. Amino acids treatment increased soil micronutrient availability as mentioned previously in Table (2) through decreasing the 
soil PH; other possibility is chelation mechanism; amino acid ligands may surround and protect the micronutrients from adverse interactions in the experimental soil (Sekhon
,2003) .Moreover, humic sub. complexes (chelates) with $\mathrm{K}, \mathrm{Mn}, \mathrm{Zn}, \mathrm{Ca}, \mathrm{Fe}, \mathrm{Cu}$ and various other elements to regulate their bioavailability in soil (Bohn et al. 2001).

Table 5. Effect of amino acids, humic substance and their combination, on some macro and micronutrient availability( mgkg-1) of studied soil at harvesting stage for both studied seasons. ( mgkg-1)

\begin{tabular}{|c|c|c|c|c|c|c|c|c|c|c|c|c|c|c|}
\hline \multirow{3}{*}{ Treatments } & \multicolumn{7}{|c|}{ First season } & \multicolumn{7}{|c|}{ Second season } \\
\hline & \multicolumn{3}{|c|}{$\begin{array}{l}\text { Macronutrients } \\
\left(\text { mgkg }^{-1}\right)\end{array}$} & \multicolumn{4}{|c|}{$\begin{array}{l}\text { Micronutrients } \\
\left(\mathrm{mgkg}^{-1}\right)\end{array}$} & \multicolumn{3}{|c|}{$\begin{array}{l}\text { Macronutrients } \\
\left(\mathrm{mgkg}^{-1}\right)\end{array}$} & \multicolumn{4}{|c|}{$\begin{array}{l}\text { Micronutrients } \\
\left(\mathrm{mgkg}^{-1}\right)\end{array}$} \\
\hline & $\mathbf{N}$ & $\mathbf{P}$ & $\mathbf{K}$ & $\mathbf{F e}$ & Mn & $\mathrm{Zn}$ & $\mathbf{C u}$ & $\mathbf{N}$ & $\mathbf{P}$ & $\mathbf{K}$ & Fe & Mn & $\mathbf{Z n}$ & $\mathbf{C u}$ \\
\hline Control & 112 & 7.53 & 240 & 6.90 & 3.28 & 0.653 & 0.666 & 85 & 4.62 & 198 & 4.59 & 2.10 & 1.13 & 0.26 \\
\hline Amino Acids 1 & 142 & 8.58 & 263 & 7.54 & 4.07 & 0.873 & 0.645 & 101 & 5.44 & 217 & 5.09 & 2.54 & 1.18 & 0.39 \\
\hline Amino Acids 2 & 172 & 9.25 & 312 & 10.94 & 4.10 & 1.05 & 0.733 & 128 & 6.20 & 255 & 7.00 & 2.66 & 1.40 & 0.44 \\
\hline Humic substance 1 & 118 & 11.9 & 307 & 10.73 & 3.94 & 0.88 & 0.690 & 103 & 6.25 & 243 & 6.37 & 2.57 & 1.32 & 0.26 \\
\hline Humic substance 2 & 144 & 13.2 & 344 & 11.88 & 4.73 & 1.31 & 0.838 & 118 & 8.32 & 315 & 8.60 & 3.06 & 1.62 & 0.37 \\
\hline Amino humate 1 & 131 & 10.9 & 286 & 10.76 & 3.82 & .767 & 0.65 & 106 & 6.24 & 226 & 6.34 & 2.36 & 1.15 & 0.36 \\
\hline Amino Humat 2 & 160 & 12.6 & 326 & 11.04 & 4.28 & 0.92 & 0.747 & 121 & $7.68 b$ & 260 & 7.10 & 2.78 & 1.28 & 0.32 \\
\hline LSD 0.05 & 9.45 & 0.465 & 19.20 & 0.151 & 0.347 & 0.084 & 0.117 & 6.98 & 0.271 & 9.12 & 0.262 & 0.229 & 0.054 & 0.021 \\
\hline
\end{tabular}

Element status of grown wheat:

\section{- Macronutrients}

Table (6) indicated that values of $\mathrm{N}, \mathrm{P}$ and $\mathrm{K}$ contents of both grains and straw for grown wheat, generally increased due to application either amino acids and humic substance applied alone or in combination as compared to control treatment; this trend was true for both studied seasons.

Table 6. Effect of amino acids, humic substances and their combination, on the status (\%) of some macronutrients of both straw and grain of grown wheat .

\begin{tabular}{|c|c|c|c|c|c|c|c|c|}
\hline \multirow[t]{3}{*}{ Treatments } & \multicolumn{4}{|c|}{ Straw } & \multicolumn{4}{|c|}{ Grains } \\
\hline & $\overline{\mathbf{N}}$ & $\mathbf{P}$ & $\mathbf{K}$ & $\mathbf{N a}$ & $\mathbf{N}$ & $\mathbf{P}$ & $\mathbf{K}$ & $\mathbf{N a}$ \\
\hline & \multicolumn{8}{|c|}{ First Season } \\
\hline Control & 0.736 & 0.173 & 2.06 & 1.12 & 1.875 & 0.338 & 0.449 & 0.228 \\
\hline Amino Acids 1 & 0.904 & 0.221 & 2.61 & 1.09 & 2.304 & 0.474 & 0.513 & 0.179 \\
\hline Amino Acids 2 & 1.028 & 0.225 & 3.02 & 1.32 & 2.71 & 0.495 & 0.716 & 0.186 \\
\hline Humic substance 1 & 0.760 & 0.214 & 3.15 & 1.44 & 2.485 & 0.569 & 0.536 & 0.198 \\
\hline Humic substance 2 & 0.864 & 0.219 & 3.67 & 1.12 & 2.553 & 0.659 & 0.928 & 0.233 \\
\hline Amino humate 1 & 0.772 & 0.193 & 2.67 & 1.33 & 2.357 & 0.541 & 0.532 & 0.175 \\
\hline Amino humate 2 & 0.924 & 0.222 & 3.24 & 1.26 & 2.567 & 0.579 & 0.768 & 0.150 \\
\hline \multirow[t]{2}{*}{ LSD 0.05} & 0.157 & 0.026 & 0.247 & 0.217 & 0.147 & 0.091 & 0.088 & 0.028 \\
\hline & \multicolumn{8}{|c|}{ Second Season } \\
\hline Control & 0.992 & 0.12 & 1.77 & 1.17 & 1.52 & 0.350 & 0.40 & 0.288 \\
\hline Amino Acids 1 & 1.16 & 0.13 & 2.27 & 1.34 & 2.00 & 0.37 & 0.54 & 0.180 \\
\hline Amino Acids 2 & 1.28 & 0.16 & 2.64 & 1.17 & 2.35 & 0.43 & 0.69 & 0.160 \\
\hline Humic substance 1 & 1.02 & 0.11 & 2.85 & 1.20 & 2.03 & 0.45 & 0.54 & 0.198 \\
\hline Humic substance 2 & 1.12 & 0.12 & 3.26 & 0.94 & 2.21 & 0.47 & 0.74 & 0.29 \\
\hline Amino humate 1 & 1.03 & 0.07 & 2.45 & 1.11 & 2.05 & 0.59 & 0.64 & 0.175 \\
\hline Amino humate 2 & 1.18 & 0.13 & 2.92 & 1.05 & 2.34 & 0.62 & 0.69 & 0.150 \\
\hline LSD 0.05 & 0.157 & 0.0425 & 0.404 & 0.217 & 0.4196 & 0.0224 & 0.188 & 0.0323 \\
\hline
\end{tabular}

Results indicated that content of ( N, P and K) for wheat grains and straw increased significantly due to the application of amino acids ,high rate (A2) being superior for nitrogen content at both studied season. Similar results were recorded by Subbarao et al.,(2015) who stated that protein hydrolysates containing amino acids and peptides are known to have bio-stimulant like activity; protein hydrolysate application stimulates root and shoot growth in the tested crops, influence higher uptake of water as well as nutrients

Similar responses were obtained with humic substances whose high rate (H2) was, again, more beneficial; the obtained results agree with those obtained by Manzoor et al.(2014) who suggested that application of humic acids improved soil nutrients availability. Also, Verlinden et al., (2009) previously suggested the existence of a synergistic effect of combined applications of mineral nutrients and humic substances. Humic substances behave like weak acid polyelectrolytes, the occurrence of anionic charged sites accounts for the ability to retain cations like
$\mathrm{K}^{+}$and $\mathrm{Mg}^{++}$; the cation exchange capacity of soil will being affected.

The positive response of applied humic substances for the nutrient contents in both grains and straw for both studied seasons is in agreement with those of Canellas et al.,( 2002) who suggested that humic substances play a role in the modulation of nitrate uptake and the plasma membrane H+ ATPase activity. The enhancement uptake of phosphorous in plants receiving humic substances was mainly reported to be due to the increased availability of phosphate in the soil; the major involved mechanism was suggested to be interference with calcium phosphate precipitation (Satisha and Devarajan, 2005). In general, humic substances application increases root mass and volume ( Eyheraguibel et al., 2008), which is an important factor in nutrient uptake .

Statistical interaction analyses revealed that values of, $\mathrm{N}, \mathrm{P}$ and $\mathrm{K}$ contents of grown wheat plants increased significantly with amino acids combined with humic substances compared to control treatment at both studied seasons. 


\section{- Micronutrients}

Data shown in Table (7) observed that all applied treatments increased significantly wheat micronutrients content ( $\mathrm{Fe}, \mathrm{Mn}, \mathrm{Zn}$ and $\mathrm{Cu}$ ) as compared to control treatment at both studied seasons.

Concerning the effect amino acids, results indicated that the concerned values were significantly affected ; (A2) was superior compared to (A1). Similar results were reported by Sekhon (2003) who found that, natural amino acids have the ability to chelate the micronutrients in soil solution and hence they are rapidly absorbed, translocated and metabolized by plants. Similar results were obtained for humic substance; (H2) gave high values of micronutrients contents for both grains and straw of grown wheat at both seasons. This may be due to the fact that, humic substance plays an important role in improving the bioavailability of nutrients to plants and through reducing the adverse effect of some of free ions through chelation capability (Yingei ,1988).

Again, to make the picture more clearly, it was thought useful to express the obtained results are shown in Tables $(6,7)$ Which indicated significant increases as consequence of applied amino acids in the presence of humic substances; amino acids combination with high rate of humic acids (AH2) were more responded as compared with (AH1).

Generally, the behavior of macronutrients and micronutrients content followed the same trend of those recorded by yield components.

Table 7. Effect of amino acids, humic substances and their combination, on the status (mg/kg) of some micronutrients of both straw and grain of grown wheat .

\begin{tabular}{lcccccccc}
\hline Treatments & \multicolumn{4}{c}{ Straw } & \multicolumn{3}{c}{ Grains } \\
\cline { 2 - 9 } & Fe & Mn & Zn & Cu & Fe & Mn & Zn & Cu \\
\cline { 2 - 9 } & & & & First Season & & & \\
\hline Control & 109 & 24.33 & 10.50 & 1.91 & 89.0 & 31 & 18 & 3.60 \\
Amino Acids 1 & 125 & 21.90 & 14.63 & 1.77 & 110 & 38 & 22 & 4.00 \\
Amino Acids 2 & 144 & 29.03 & 15.77 & 2.37 & 121 & 50 & 23 & 4.33 \\
Humic substance 1 & 142 & 28.38 & 16.43 & 2.93 & 102 & 44 & 18 & 5.93 \\
Humic substance 2 & 145 & 38.77 & 18.53 & 2.57 & 132 & 54 & 32 & 7.10 \\
Amino humate 1 & 126 & 23.03 & 13.33 & 1.80 & 105 & 37 & 20 & 5.57 \\
Amino humate 2 & 139 & 34.96 & 15.07 & 1.63 & 123 & 51 & 30 & 5.60 \\
LSD 0.05 & 23.75 & 7.36 & 3.53 & 0.44 & 11.18 & 6.41 & 5.58 & 1.66 \\
\hline & & & & Second Season & & 28 & \\
Control & 118.9 & 33.4 & 23.63 & 0.63 & 86.87 & 28.73 & 20.47 & 2.10 \\
Amino Acids 1 & 134.7 & 37.6 & 27.8 & 0.67 & 119 & 33.97 & 23.5 & 2.70 \\
Amino Acids 2 & 132.2 & 41.47 & 29.2 & 0.60 & 138 & 50.95 & 29.26 & 3.26 \\
Humic substance 1 & 135.3 & 38.83 & 27.6 & 0.50 & 130 & 48.83 & 31.13 & 3.13 \\
Humic substance 2 & 155.3 & 46.4 & 38.6 & 0.43 & 149 & 53.33 & 40.67 & 3.5 \\
Amino humate 1 & 124.2 & 36.2 & 25.2 & 0.53 & 137 & 36.73 & 29.2 & 4.10 \\
Amino humate 2 & 135.0 & 42.17 & 31.78 & 0.53 & 139 & 49.2 & 35.33 & 3.93 \\
LSD 0.05 & 34.61 & 6.65 & 9.758 & 0.155 & 12.15 & 6.1627 & 4.541 & 0.118 \\
\hline
\end{tabular}

- $\mathrm{K} / \mathrm{Na}$ of wheat plant.

Data presented in Fig. ( 1 ) indicated a significant increase in $\mathrm{K} / \mathrm{Na}$ ratio in presence each of amino acid and humic substances along with their combination as compared to control; such ratio increased by increasing the rate of applied treatments.

Generally, the positive effect of applied treatments on $\mathrm{K} / \mathrm{Na}$ ratio , of both tested seasons may be arranged in the descending order of amino-humate $2>$ amino acid $2>$ humic sub. $2>$ amino-humate $1>$ amino acid $1>$ humic sub 1 as compared to control. These results were explained by Shabala and Cuin( 2008) who reported that high level of proline regulates plasma membrane $\mathrm{K}$ ion channels which are directly effect in the $\mathrm{K} / \mathrm{Na}$ ratio. Similar results were reported by Abd El-Samad et al.(2010) who found that, amino acids treatments enhanced the uptake of $\mathrm{K}^{+}$, and hence, $\mathrm{K}^{+} / \mathrm{Na}^{+}$ratio to be increased .
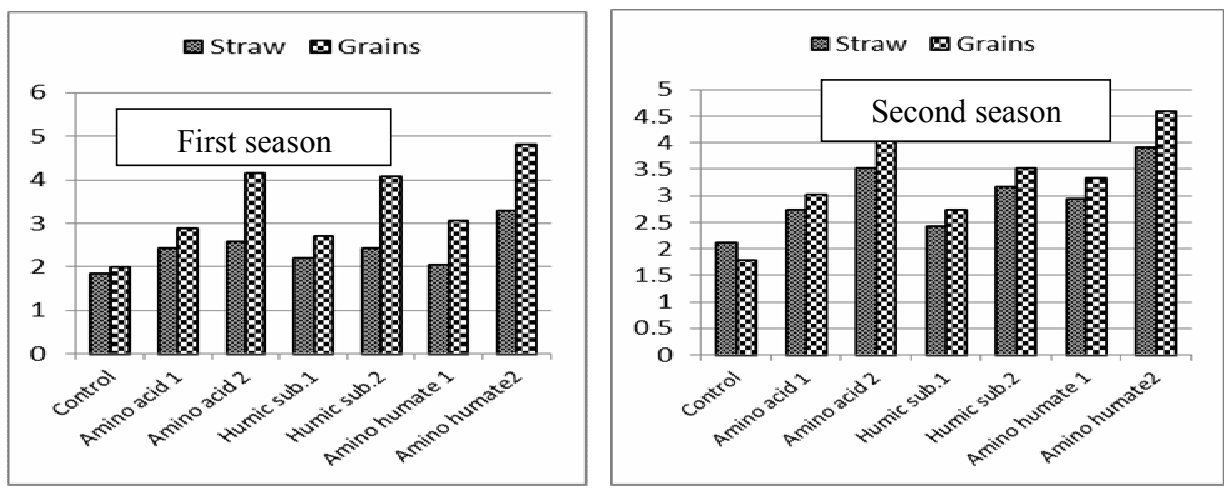

Fig. 1. Effect of amino acids, humic substances and their combination on $\mathrm{K} / \mathrm{Na}$ ratio, for both straw and grain of grown wheat . 


\section{Organic components and chlorophyll content \\ - Crude protein (CP):}

Results presented in Fig. (2) revealed that increasing the rate of applied amino acids or humic substances, either separately or in combination, caused a positive increase in crude protein $(\mathrm{CP}) \%$ in grains of wheat crop for both tested seasons as compared to control treatment. Similar results were recorded by Sadak et al.(2015) who found that presence of amino acids increase the crude protein due to enhancement in plant growth as a result of more protein synthesis. Also Vaccaro (2015) recorded that humic substance( HS ), influenced positive nitrate metabolism by increasing the content of protein and amino acids synthesis. Furthermore, the activity and transcription of enzymes functioning in $\mathrm{N}$ assimilation and Krebs cycle were significantly stimulated.
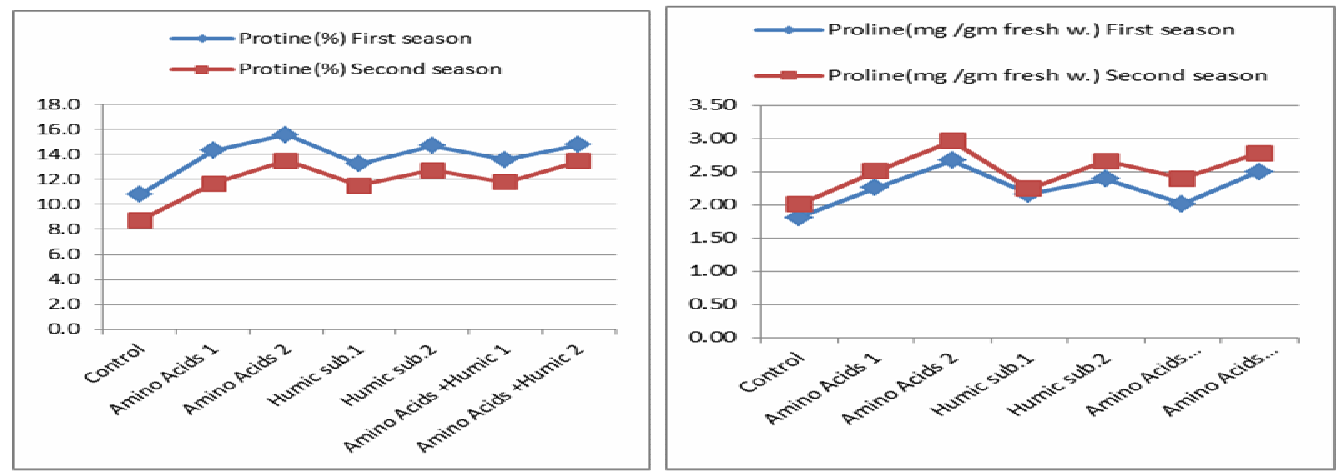

Fig. 2. Effect of amino acids, humic substance and their combination on crude protein (CP) and proline for grown wheat .

\section{- Proline content:}

Accumulation of compatible solutes such as proline is one of the most important mechanisms attained by higher plants under salt-stress is the Proline accumulation in salt stressed plants is a primary defense response to maintain the osmotic pressure in a cell.

Data presented in Fig. (2) indicated a significant increase in proline content ( $\mathrm{mg} / \mathrm{gm}$ fresh w.) in presence of either amino acids, humic substances or their combination as compared to control. Proline content increased by increasing the rate of applied treatments; proline is one of the amino acids required by plants under stress condition. Obtained results agree with those Khanna and Rai (1998) who observed that amino acids application increased proline content under osmotic stress. Moreover, Ertani et al., (2013) added that root application of amino acids improved salinity tolerance of corn plants due to proline accumulation in leaves. Similar results were obtained by

Rady( 2012)who found that, HS enhanced the level of proline under salt stress

\section{- Chlorophyll content}

Data presented in Fig (3) show the changes of leaf total chlorophyll content in presence of either amino acids , humic substance or their combination. Values leaf total chlorophyll content( $\mathrm{A}, \mathrm{B}$ and $\mathrm{A}+\mathrm{B})$, increased significantly in all tested treatments as compared to control, high rates being more effective. Results also showed that application of high rate of amino acids (A2) was superior as compared to control and other treatments, possibly due to effects on nitrogen metabolism in plant as to justify the $\mathrm{N}$-use efficiency . Results agree with those of Vernieri et al., (2006), as well as El-Bassiouny et al.(2014) who found that, humic acid possibly caused an increase in the synthesis of the chlorophyll or delayed chlorophyll degradation.
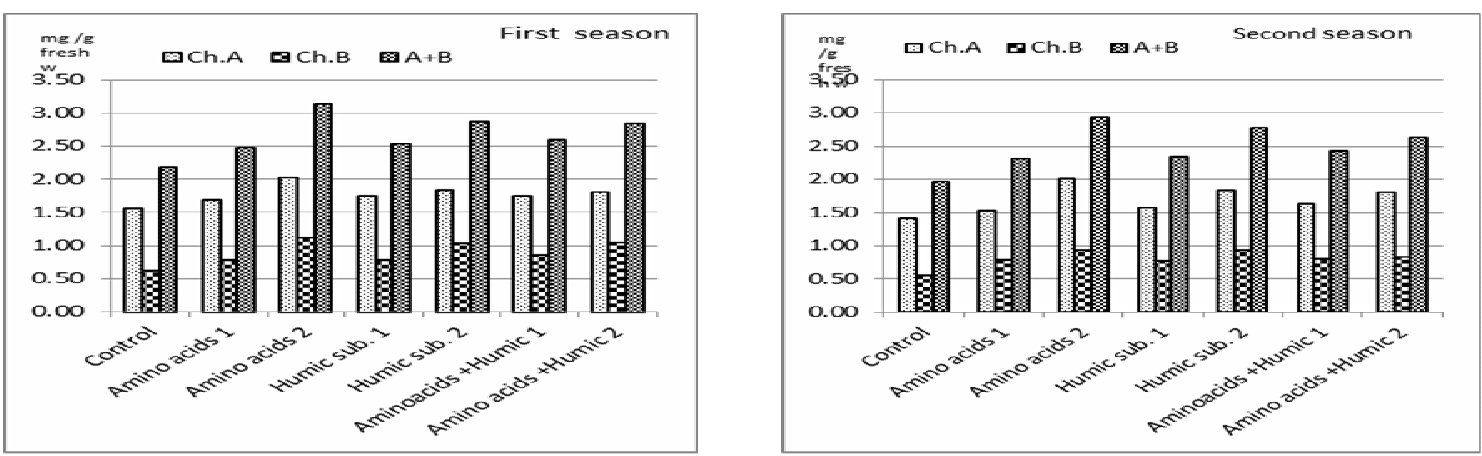

Fig. 3. Effect of amino acids, humic substance and their combination, on leaf total chlorophyll content of grown wheat.

Yield components of wheat crop:

Data presented in Table (8) revealed that wheat yield components (straw and grains) of both studied

seasons were significantly stimulated due to applied treatments of both amino acid and humic substance as compared to control. Increasing the rate of applied amino acid from $\mathrm{A} 1$ to $\mathrm{A} 2$ and humic substance from $\mathrm{H} 1$ to $\mathrm{H} 2$ 
caused a significant increase for both studied seasons under investigation; this is possibly due to the fact that amino acids are considered as precursors and constituents of proteins (Rai, 2002), which are important for stimulation of cell growth. Amino acids is a biostimulant which have positive effects on plant growth, yield and significantly mitigates the injuries caused by abiotic stresses ;several alternative routes of Indol AceticAcid synthesis in plants, all starting from amino acids (Kowalczyk and Zielony, 2008). The obtained results are confirmed by Sadak et al., (2015) who found that, application of amino acids may provide a source of growing substances which form the constitutes of protein in the living tissues. Also, the positive effects of amino acids application may be brought about by its cell-internal function as osmo-regulatory which can increase the concentration of cellular osmotic components. Responses of humic substances may be due to a significant increase in mineral nutrient uptake by plants, receiving humic acid in saline medium ,probably increasing the permeability of membranes of root cells. The humic substance may also act through a stimulation of both root growth and proliferation. These effects are particularly important for the adaptation of plants to adverse soil conditions, such as salinity and could be useful for the definition of rhizosphere management practices (Romheld and Neumann, 2006); the improvement of nutrient uptake, particularly of micronutrients, might be important to increase plant resistance to biotic and abiotic stresses. Also, HS increases the lateral root emergence and induce the production of smaller, but more ramified, secondary roots. Similar results were obtained by Brunetti et al. (2007) who found a positive correlation between wheat grain yield and humic substance.

Results also indicated that the treatment of (aminohumate2) was more responded for increasing both yield components of straw and grains as compared to ( aminohumate1) for both studied seasons.

Generally, the positive effect of applied treatments on yield components of both tested seasons may be arranged in descending order of, humic sub. $2>$ aminohumate $2>$ amino acid $2>$ humic sub. $1>$ amino-humate 1 $>$ amino acid 1 as compared to control treatment.

Table 8. Effect of amino acids, humic substance and their combination on yield components of wheat crop (ton fed $\left.{ }^{-1}\right)$.

\begin{tabular}{lcccccccc}
\hline & \multicolumn{3}{c}{ First season } & \multicolumn{4}{c}{ Second season } \\
\cline { 2 - 9 } Treatments & Straw & Increasing(\%) & Grains & Increasing(\%) & Straw & Increasing(\%) & Grains & Increasing(\%) \\
\hline Control & 2.00 & & 1.87 & & 2.03 & & 1.74 & \\
Amino Acids 1 & 2.48 & 24.0 & 2.27 & 21.39 & 2.25 & 10.83 & 2.13 & 20.69 \\
Amino Acids 2 & 3.07 & 53.5 & 2.72 & 45.45 & 2.64 & 30.05 & 2.50 & 43.68 \\
Humic substance 1 & 2.67 & 33.5 & 2.61 & 39.57 & 2.50 & 23.15 & 2.28 & 31.03 \\
Humic substance 2 & 3.22 & 61.0 & 2.94 & 57.22 & 3.20 & 57.63 & 2.76 & 58.62 \\
Amino humate 1 & 2.57 & 28.5 & 2.43 & 29.95 & 2.49 & 22.66 & 2.23 & 28.16 \\
Amino humate 2 & 3.05 & 52.5 & 2.91 & 55.61 & 2.90 & 42.86 & 2.67 & 53.45 \\
LSD 0.05 & 0.163 & & 0.193 & & 0.121 & & 0.265 & \\
\hline
\end{tabular}

\section{CONCLUSION}

Form the obtained results, concluded that application of amino acids (A), humic substances $(\mathrm{H})$ or amino humate $(\mathrm{AH})$ might counteract the negative effects of salinity and induced an overall positive effect on each of soil chemical properties as well as nutrient availability of soil after plant harvesting. $\mathrm{pH}$ values, in general were slightly affected by the studied treatments, values of EC and ESP were positively affected with lowest EC in presence of humic substaces $(\mathrm{H} 2)$; Positive response was also detected for each of CEC, O.M . Significant affects were observed in nutrient availability as well as element status of grown wheat; the second rate of amino acid (A2) giving the highest values of available $\mathrm{N}$ and nitrogen content followed by the second rate of amino humate (AH2); the high rate of humic substances $(\mathrm{H} 2)$ was more effective for increasing $\mathrm{P}, \mathrm{K}$ and micronutrients (Fe, $\mathrm{Mn}, \mathrm{Zn}$ and $\mathrm{Cu}$ ) availability followed by the second rate of amino humate (AH2). Results also ,showed that application of high rate of amino acids (A2) was superior for increasing the leaf total proline, Chlorophyll and grain protein content ; positive effect of applied treatments on $\mathrm{K} / \mathrm{Na}$ ratio may be arranged in the descending order of amino-humate $2>$ amino acid $2>$ humic sub. $2>$ aminohumate1 $>$ amino acid $1>$ humic sub. 1 as compared to control.

Finally, increasing the rate each of amino acids or humic substances and their combination caused a significant increase in straw and grains of wheat for both studied seasons; humic sub.( $\mathrm{H} 2$ ) was superior as compared with amino acid (A1) which was the inferior.

\section{REFERENCES}

Abd El-Samad, H. M., Shaddad, M. A. K. and Barakat, N. (2010). The role of amino acids in improvement in salt tolerance of crop plants. J. Stress Physiol. Biochem. 3: 25-37.

Aydin,A., Kant, C. and Turan, M. (2012). Humic acid applications alleviate salinity stress of bean (Phaseolus vulgaris L.) plants decreasing membrane leakage. Afr. J. Agric. Res. 7:1073-1086.

Baker, D. (1979). Report on cereal foods. J. Assoc. Off. Anal. Chem. 62: 369 -370.

Bates, L.S., Waldren, R.P. and Reare, I.D. (1973). Rapid determination of free proline for water stress studies. Plant and Soil, 39, 205-207.

Bohn, H.L., McNeal, B.L. and O’Connor, G. A (2001). "Soil Chemistry". A Wiley Interscience Publication. John Wiley and Sons, New York.

Brady, N.C., and Weil, R.R. (2008). "The nature and properties of soils". Pearson Prentice Hall, Upper Saddle River, N.J.

Brunetti, G., Senesi, N. and Plaza, C. (2007). Effects of amendment with treated and untreated olive oil mill wastewaters on soil properties, soil humic substances and wheat yield. Geoderma. 138: 144152. 
Calvo, P., Nelson, L. and Kloepper, J.W. (2014). Agricultural uses of plant biostimulants. Plant and Soil 383: 3-41.

Canellas, L.P., Olivares, F.L., Okorokova-Façanha, A.L. and Façanha, A.R. (2002). Humic acids isolated from earthworm compost enhance root elongation, lateral root emergence and plasma membrane $\mathrm{H}^{+}$ATPase activity in maize roots. Plant Physiol. 130: 1951-1957.

Clapp, C.E., Chen, Y., Hayes, M.H.B. and Cheng, H.H. (2001). Plant growth promoting activity of humic substances. In: Swift RS, Sparks KM, editors. Understanding and Managing Organic Matter in Soils, Sediments and Waters. St. Paul: International Humic Science Society, 243-255.

Colla, G., Rouphael, Y., Canaguier, R., Svecova, E. and Cardarelli, M. (2014). Biostimulant action of a plant-derived protein hydrolysate produced through enzymatic hydrolysis. Front Plant Sci. , 5: 448.

Cottenie, A., Verloo, M., Velghe, G. and Cameriynck ,R. (1982). "Chemical analysis of plant and soil." Laboratory of analytical and agrochemistry, State Univ., Ghent, Belgium.

El-Bassiouny, H.S.M., Bakry, A.B., Abd El-Monem, A. and Abd Allah, M.M. (2014). Physiological role of humic acid and nicotinamide on improving plant growth, yield, and mineral nutrient of wheat (Triticum durum) grown under newly reclaimed sandy soil. Agric. Sci., 5: 687-700.

Ertani, A., Cavani, L., Pizzeghello, D., Brandellero, E., Altissimo, A., Ciavatta, C. and Nardi, S. (2009). Biostimulant activity of two protein hydrolyzates in the growth and nitrogen metabolism of maize seedlings. J. Plant Nutr.and Soil Sci. 172:237-244.

Ertani, A., Schiavon, M., Muscolo, A. and Nardi, S. (2013). Alfalfa plant-derived biostimulant stimulate short-term growth of salt stressed Zea mays L. plants. Plant and Soil 364: 145-158 .

Eyheraguibel, B., Silvestre, J. and Morard, P. (2008). Effects of humic substances derived from organic waste enhancement on the growth and mineral nutrition of maize. Biores. Technol. 99: 4206-4212.

FAO.,( 2004). Scaling soil nutrient balances: Enabling Meso- Level Applications for African Realities Fertilizer and Plant Nutr. Buletin, No. 15. Food and Agriculture Organization Rome.

Gioseffi E., de Neergaard, A. and Schjoerring, J.K. (2012). Interactions between uptake of amino acids and inorganic nitrogen in wheat plants. Biogeosci. 9: 1509-1518.

Jackson, M. L. (1967). "Soil Chemical Analysis", PrinticeHall of India, New Del.

Jiangkuan, N., Chen, X., Wang, X., Lashari, M.S., Wang, Y., Guo, Z. and Du, Z. (2015). Effects of applying flue gas desulfurization gypsum and humic acid on soil physicochemical properties and rapeseed yield of a saline-sodic crop land in the eastern coastal area of China. J. Soils Sediments.

Jones, D., Clode, P., Kilburn, M. R., Stockdale, E. A. and Murphy, D.V. (2013). Competition between plant and bacterial cells at the microscale regulates the dynamics of nitrogen acquisition in wheat (Triticum aestivum) New Phytol. 3: 796-807.
Khaled, H. and Fawy, H. A.(2011). Effect of different levels of humic acids on the nutrient content, plant growth and soil properties under conditions of salinity, Soil Water Res. $1: 21-29$.

Khanna, S. and Rai, V.K. ( 1998).Changes in proline levels in response to osmotic stress and exogenous amino acids in Raphanus sativus L. seedlings. Acta Physiol. Plant. 20: 393-397.

Khattak, R.A, Haroon, K. and Muhammad, D. (2013) Mechanism(s) of humic acid induced beneficial effects in salt-affected soils. Acad. J. 8:932-939.

Kowalczyk, K. and Zielony, T. (2008). Effect of amino plant and asahi on yield and quality of lettuce grown on rock wool. Conf. of biostimulators in modern agriculture, 7-8 Febuary, Warsaw, Poland.

Kulikova, N.A., Stepanova, E.V. and Koroleva, O.V. (2005). "Mitigating activity of humic substances: direct influence on biota. Use of humic substances to remediate polluted environments: from theory to practice". I.V. Perminova 1. (eds.).

Lakhdar, A., Rabhi, M., Ghnaya, T., Montemurro, F., Jedidi, N. and Abdelly, C. (2009). Effectiveness of compost use in salt-affected soil. J. Hazard. Mater. 171: 29-37.

Lauchli, A. and Epstein, E. (1990). "Plant response to salinity and sodic conditions. In:Agricultural Salinity Assesment and Management" (Ed. K.K. Tanji). Amer. Soc. Civil Eng., Manual and Report Engineering Practice. 71:113-137.

Lichtenthaler, H. K. and Wellburn, A.R. (1983). Determination of total carotenoids and chlorophylls $\mathrm{a}$ and $\mathrm{b}$ of leaf in different solvents. Biol. Soc. Trans. 11: 591-592.

Manzoor, A., Khattak, R. A. and Dost, M. (2014). Humic acid and micronutrient effects on wheat yield and nutrients uptake in salt affected soils. Int. J. Agric. Biol., 16: 991-995.

Ouni, Y., Ghnaya, T., Montemurro, F., Abdelly, C. and Lakhdar, A.( 2014).The role of humic substances in mitigating the harmful effects of soil salinity and improve plant productivity. Int. J. Plant Prod. 8: 353-374.

Rady, A.A. (2012). A novel organo-mineral fertilizer can mitigate salinity stress effects for tomato production on reclaimed saline soil. South Afr. J. Bot. 81: 8-14.

Rai, V.K. (2002). Role of amino acids in plant responses to stress. Biol Plant. 45:471-478.

Romero-Aranda, R., Soria, T. and Cuartero, J. ( 2001). Tomato plant water uptake and plant water relationships under saline growth conditions. Plant and Science. 160: 265-272.

Römheld, V. and Neumann, G. (2006)." The Rhizosphere: Contributions of the soil-root interface to sustainable soil systems". In: Uphoff, $\mathrm{N}$. et al. (ed.) Biological Approaches to Sustainable Soil Systems. CRC Press, Boca Raton, FL. 91-107.

Sadak, S.H. M., Abdelhamid, M. T. and Schmidhalter, U. (2015). Effect of foliar application of amino acids on plant yield and physiological parameters in bean plants irrigated with seawater. Acta biol. Colomb. 1:141-152. 
Satisha, G. and Devarajan, L. (2005). Humic substances and their complexation with phosphorus and calcium during composting of press mud and other biodegradables. Communications in Soil Sci. and Plant Analysis .36:805-818.

Sekhon, B. S. (2003) .Chelates for micronutrient nutrition among crops. Resonance. $8: 46-53$.

Shabala, S. and Cuin, T.A. (2008). Potassium transport and plant salt tolerance. Physiol. Plant 133:651669.

Snedecor, G.W. and W. G. Cochran , (1980). "Statistical Methods". 7t ed . IOWA, State Univ. U.S.A.

Subbarao, S.B., Aftab Hussain, I.S. and Ganesh, P.T. (2015). Bio stimulant activity of protein hydrolysate: influence on plant growth and yield. J. Plant Sci Res. 2: 125.

Tahir, M.M., Khurshid, M., Khan, M.Z., Abbasi, M.K. and Kazmi, M.H. (2012) Lignite-derived humic acid effect on growth of wheat plants in different soils. Pedosphere 21:124-131.

Vaccaro, S., Ertani, A., Nebbioso, A., Muscolo, A., Quaggiotti, S., Piccolo, A. and Nardi, S.(2015)."Humic substances stimulate maize nitrogen assimilation and amino acid metabolism at physiological and molecular level". Chemical and Biological Tech. in Agric. 2:5.
Valdrighi, M. M., Pera, A., Agnolucci, M., Frassinetti, S., Lunardi, D. and Vallini, G. (1996). Effects of compost-derived humic acids on vegetable biomass production and microbial growth within a plant (Cichoriwn intybur)-soiI system: a comparative study. Agric., Ecosys. and Environ. 58: $133-144$

Verlinden, G., Pycke, B. , Mertens, J., Debersaques, F. , Verheyen, K. , Baert, B., Bries, J. and Haesaert, G.( 2009). Application of humic substances results in consistent increases in crop yield and nutrient uptake. J. Plant Nutr. 32: 1407-1426.

Vernieri, P., Ferrante, A., Borghesi, E. and Mugnai, S. (2006). Biostimulants: a tool for improving quality and yield. Biostimolanti: uno strumento per migliorare la qualità delle produzioni. Fertilitas Agrorum 1: 17-22 (in Italian, with abstract in English).

Wendell, O. ( 2002). "Zwitterions" 7th Watershed Heroes Core 4 Conference and National Eco Team Competition. ST. Peter, Minnesta, June 19-21.

Wong, V.N.L., Dalal, R.C. and Greene, R.S.B. (2009). Carbon dynamics of sodicand saline soils following gypsum and organic material additions: a laboratory incubation. Appl Soil Ecol 41:29-40.

Yingei, W.(1988). HA resin treatment of copper and nickle. Haunjing Bashu., 7:21-22.

\section{تـأثير اضــافة الأحمـاض الأمينيـة والموادالهيوميـة علـي بعض الخـواص الكيميائية للتربـة والحالـة الغذائيسة وانتاجيـة محصول القمح النامي تحت الظروف الأينة الملحية

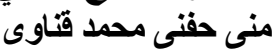 معهد بحوث الاراضى و المياه و البيئة ـ مركز البحوث الزراعية ـ الجيزة ـ مصر}

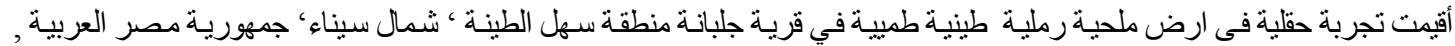

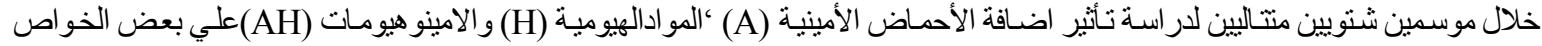

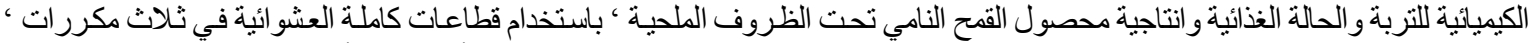

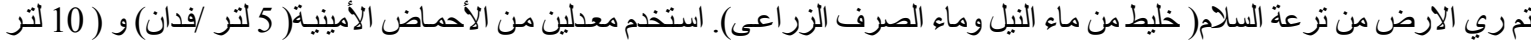

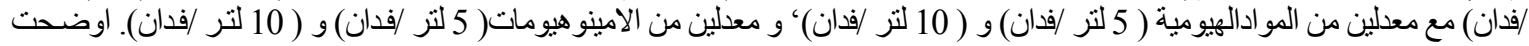

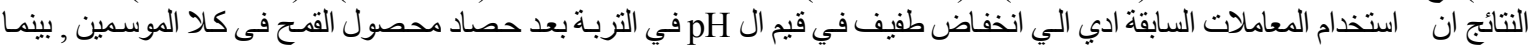

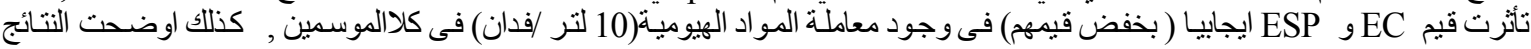

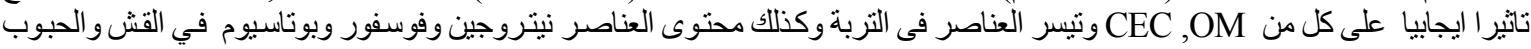

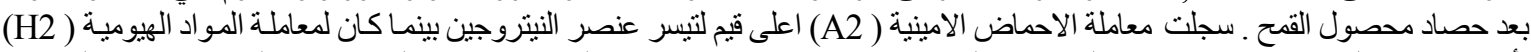

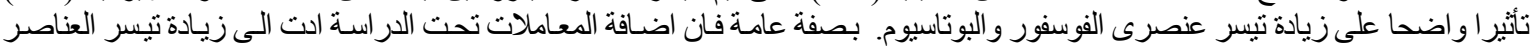

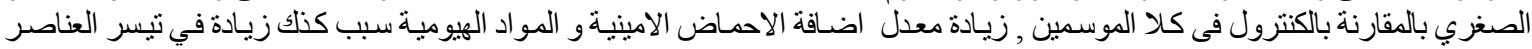

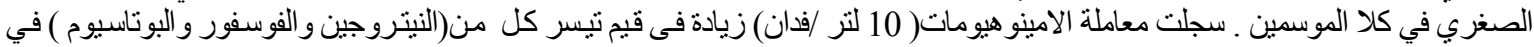

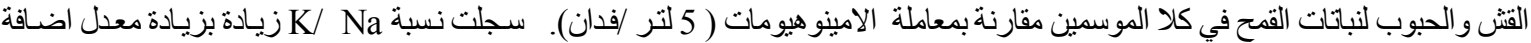

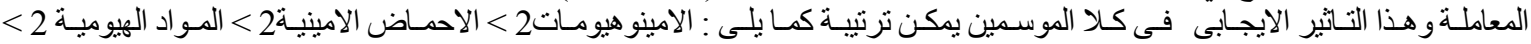

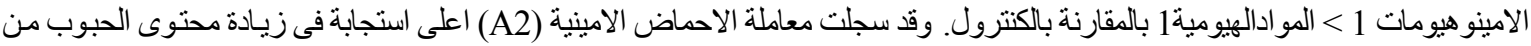

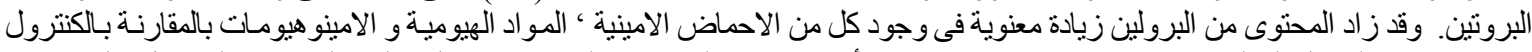

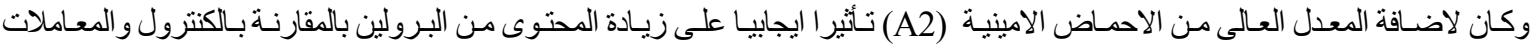

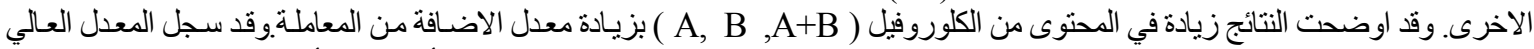

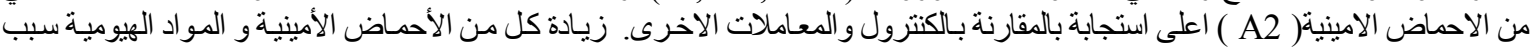

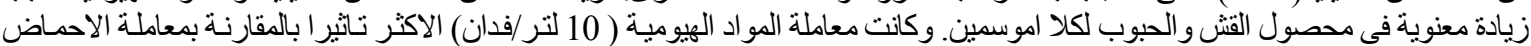

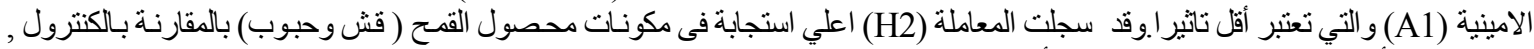
يليها معاملة الأمينو هيوماتحو التي كانت اكثر تأثير العى مكونات المحصول ( قش وحبوب) بالمقارنة بالامينو هيومات 1 فى كلا الموسمين. 